\title{
Advanced oxidation of catechol in reverse osmosis concentrate generated in leather wastewater by $\mathrm{Cu}$-graphite electrode
}

\author{
P. Maharaja ${ }^{1}$ R. Boopathy ${ }^{2}$ S. Karthikeyan' ${ }^{1}$ M. Mahesh ${ }^{1}$ - A. S. Komal ${ }^{3}$. \\ V. K. Gupta ${ }^{4,5}$ - G. Sekaran ${ }^{1}$
}

Received: 17 August 2015/Revised: 28 January 2016/Accepted: 25 June 2016/Published online: 7 July 2016

(C) Islamic Azad University (IAU) 2016

\begin{abstract}
Reverse osmosis (RO) concentrate generated from tannery was treated by advanced electrochemical oxidation using graphite electrodes. Catechol was selected as model organic pollutant in the $\mathrm{RO}$ concentrate. The influence of applied current density, catechol concentration, $\mathrm{pH}$, temperature and inner electrode space of electrodes was investigated in electrochemical oxidation system. The optimized conditions were found to be current density $(j), 100 \mathrm{~mA} / \mathrm{cm}^{2}$; electrolysis time $\left(t_{\text {eco }}\right), 60 \mathrm{~min} ; \mathrm{pH}, 7.0$; and temperature, $25{ }^{\circ} \mathrm{C}$ at an inner electrode space, $2 \mathrm{~cm}$. The average mass transport coefficient for the removal of catechol as COD was found to be $3.0 \times 10^{-5} \mathrm{~m} / \mathrm{s}$ at optimum conditions. Faradic efficiency and specific energy consumption were also calculated for the applied current density. Further, the treatment of catechol was confirmed through Fourier transform infrared spectroscopy. Theoretical evaluation of current density suggested that the removal of catechol was controlled when supplied at above limiting applied current densities and mass transport controlled at lower of limiting current densities.
\end{abstract}

G. Sekaran

sekaransabari@gmail.com

1 Environmental Technology Division, Council of Scientific and Industrial Research (CSIR), Central Leather Research Institute (CLRI), Adyar, Chennai, Tamil Nadu 600 020, India

2 Environmental \& Sustainability department, CSIR-Institute of Minerals and Materials Technology, Bhubaneswar, Odisha, India

3 School of Mechanical and Building Sciences, VIT, Vellore, India

4 Department of Chemistry, Indian Institute of Technology Roorkee, Roorkee 247 667, India

5 Department of Applied Chemistry, University of Johannesburg, Johannesburg, South Africa
Keywords RO concentrate $\cdot$ Cu-graphite $\cdot$ Refractory organics $\cdot$ Electrolysis $\cdot$ Saline solution $\cdot$ Tannery

\section{Introduction}

Among the membrane separation processes, reverse osmosis (RO) is being widely applied for sea water desalination, production of potable water and in industrial tertiary wastewater treatment. Among the membrane processes, RO is being preferred for its modular construction and small footprint, which enables to combine with other treatment process sequences (Chelme-Ayala et al. 2009; Ahmet kaya et al. 2016). However, the concentrate stream generated from RO processes demands suitable treatment before being discharged into the environment (Mauguin and Corsin 2005).

Roberts et al. (2010) have reported an issue of ecological impacts on disposal of concentrate generated from sea water desalination. There are many laboratory-based experiments, toxicological investigations and manipulative field experiments reports on the potential impact on direct discharge of brines and their constituents to aquatic system. However, the RO processes simply compresses the solute constituents from feed stream to concentrate stream, which are normally found to be double or higher than the feed steam concentration (Chelme-Ayala et al. 2009). Conventionally, the brines are being discharged after diluted with power plant cooling waters, natural seawater or municipal wastewaters to reduce salinity (Einav and Lokiec 2003; Meneses et al. 2010). The disposal of diluted concentrates could severely affect the sensitive species of environment due to the refractory nature of organic pollutants present in concentrate (Meneses et al. 2010). There 
are other alternative methods of disposal of RO concentrate are being studied and reported, such as ozonation (Pophali et al. 2011), heterogeneous photocatalysis (UV/ $\mathrm{TiO}_{2}$ ) (Westerhoff et al. 2009; Mehmet et al. 2014a, b; Muhammad et al. 2015), sonolysis (Zhou et al. 2011a, b; Muneer et al. 2015). Recently, electrochemical advanced oxidation processes (EAOPs) have attracted considerable interests for the refractory organic removal from wastewater due to their simplicity and high efficiency by hydroxyl radical production (Hege et al. 2004; Dialynas et al. 2008; Perez et al. 2010; Chaplin et al. 2010; Zhou et al. 2011a, b; Boopathy and Sekaran 2014; Necip et al. 2015). The formation of hydroxyl radicals $(\mathrm{OH})$ and secondary oxidizing agents (chlorine gas, hypochlorous acid) can effectively remove various refractory organic pollutants in the concentrate. There are reports on the electrochemical treatment of various wastewater using different anode materials, among which BDD and $\mathrm{Ti} / \mathrm{IrO}_{2-}$ $\mathrm{RuO}_{2}$ electrodes were found to be effective and dimensionally stable (Boopathy et al. 2012). The performance of electrochemical oxidation process is decided by the nature of anode material (active and non-active), and the mechanism of organic oxidation (direct and indirect) takes place during the electrochemical oxidation. Modern wastewater treatment process incorporates an integrated unit operation such as adsorption-cum-oxidation or adsorption-cum-disinfection for the minimization of time and land space. In this study, copper-coated graphite electrode was used for the treatment of prepared catechol containing RO concentrate with packed bed adsorption column for the removal of trihalomethanes. The application of tannin chemicals in leather processing generates a various byproducts among which catechol was be primary end products. Hence, in this study catechol was selected as model organic compound in the tannery RO concentrate.

\section{Materials and methods}

\section{Preparation of catechol containing RO concentrate}

Catechol containing RO concentrate was prepared by dissolving catechol $(2.25,4.5$ and $9 \mathrm{mmol} / \mathrm{L})$ at required experimental concentration in RO concentrate collected from a commercial CETP in Ranipet, Tamil Nadu, India (Murugananthan et al. 2005). All the above chemicals are procured from Merck India Ltd.

\section{Reactor set-up and experimental procedure}

A jacketed rectangular electrochemical cell (Fig. 1) (height $12 \mathrm{~cm}$, width $10 \mathrm{~cm}$ and thickness $4.5 \mathrm{~cm}$ ) was fabricated using 6-mm-thick acrylic plastic sheet for a working volume of $0.5 \mathrm{~L}$. In this reactor, two graphite rods (diameter $2.5 \mathrm{~cm}$ and length $15 \mathrm{~cm}$ ) were positioned horizontally with required experimental space $(1,2,3,4.5$ and $6.5 \mathrm{~cm}$ ) in a separate electrochemical cell. One end of the electrodes was initially coated with copper for a length of $3 \mathrm{~cm}$ (as shown in Fig. 1) for external lead to make electrical connection with DC power supplier. The used electrodes (exposed area) are allowed to soak in $1 \%(\mathrm{v} / \mathrm{v})$ (hydrochloric acid to remove any polarized salt particles and washed with distilled water twice. The washed graphite electrodes are dried in open atmosphere for next cycle of operation or wrapped using polythene plastic until any use (storage). The DC power supply (0-60 V and 0-5 A) was used to set a required current density and voltage for the electrochemical oxidation of catechol containing RO concentrate. The electrochemical cell was maintained at $25{ }^{\circ} \mathrm{C}$ by recirculation of externally temperature-controlled water pumping through jacketed medium during the experiments.
Fig. 1 Schematic diagram of electrochemical cell for the treatment of catechol containing RO concentrate

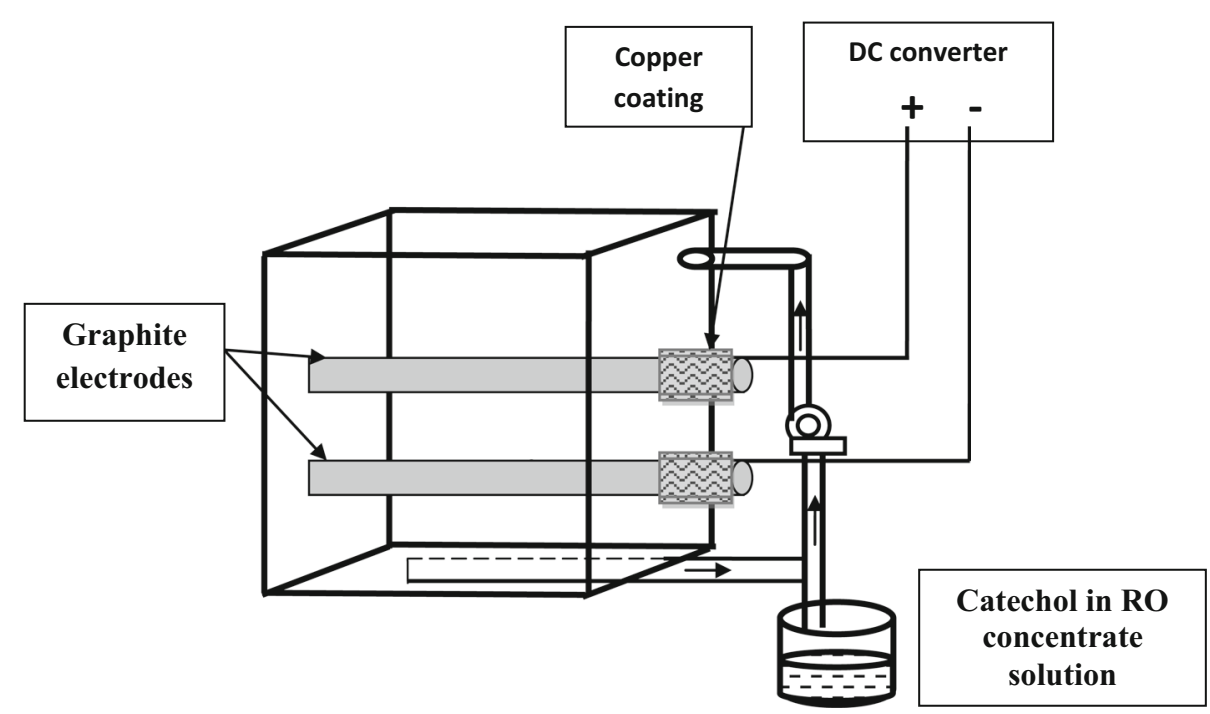


The performance of electrochemical oxidation of RO concentrate was evaluated for the applied current density (j) $\left(100,200\right.$ and $\left.300 \mathrm{~mA} / \mathrm{cm}^{2}\right)$, catechol concentration $(2.25,4.5$ and $9 \mathrm{mmol} / \mathrm{L})$ and inner electrode spacing $(1,2$, $3,4.5$ and $6.5 \mathrm{~cm}$ ). Aliquot samples were drawn to estimate the residual solution COD value, and the corresponding decrease in sample volume during the sampling was corrected by adopting the methodology described by Choo et al.(2006).

\section{Analyses}

The catechol containing synthetic RO concentrate was characterized for various parameters according to standard methods (APHA 1999). The solution is found to be high content of chloride, which is known to affect the COD determination. Hence, the COD analysis was performed by adopting methodology (specific to high saltcontaining liquid waste) described by Vyrides and Stuckey (2009). In this analysis, the digestion mixture was prepared by adding $\mathrm{K}_{2} \mathrm{Cr}_{2} \mathrm{O}_{7}, 3 \mathrm{~g}$ (which was previously dried at $103{ }^{\circ} \mathrm{C}$ for $2 \mathrm{~h}$ ), to concentrated $\mathrm{H}_{2} \mathrm{SO}_{4}$, $167 \mathrm{~mL}$ and $\mathrm{HgSO}_{4}, 33 \mathrm{~g}$ and made up to $500 \mathrm{~mL}$ with deionized water. The mixture was then left to cool at room temperature before being diluted to $1000 \mathrm{~mL}$. The sulphuric acid reagent $(2.5 \%, \mathrm{w} / \mathrm{v})$ was prepared by dissolving $\mathrm{Ag}_{2} \mathrm{SO}_{4}$ in $\mathrm{H}_{2} \mathrm{SO}_{4}$, and the sampling and digestion were carried out in accordance with methodology described under the analysis of water and wastewater. Table 1 shows physico-chemical characteristics of reverse osmosis concentrate generated from leather industry

Table 1 Physico-chemical characteristics of reverse osmosis concentrate generated from leather industry

\begin{tabular}{lll}
\hline Sl. No. & Parameters & Mean value \\
\hline 1 & $\mathrm{pH}^{\mathrm{a}}$ & 6.42 \\
2 & Conductivity $(\mathrm{mS} / \mathrm{cm})$ & 34.86 \\
3 & Total dissolved solids & 15,240 \\
4 & Chemical oxygen demand & 250 \\
5 & Total organic carbon & 220 \\
6 & Total Kjeldahl nitrogen & 46 \\
7 & Ammonia nitrogen & 25 \\
8 & Calcium & 1124 \\
9 & Magnesium & 13.8 \\
10 & Chloride & 9996 \\
11 & Sulphate & 3020 \\
\hline
\end{tabular}

a All the parameters are expressed in $\mathrm{mg} / \mathrm{L}$, except $\mathrm{pH}$ and conductivity

\section{Theoretical approach}

The mechanism of electrochemical oxidation of organic pollutants is a complex phenomenon involving the coupling of electron transfer reaction with a dissociate chemisorption step. Basically, two types of oxidative mechanism are observed with respect to the oxidant generation: Oxidation occurring at the electrode surface is called as direct electrolysis and oxidation occurring via the oxidant generated continuously on the anodic surface is called indirect electrolysis. In direct electrolysis, the rate of oxidation is depending on electrode activity, pollutants diffusion rate and applied current density. In direct electrolysis, first, $\mathrm{H}_{2} \mathrm{O}$ is discharged at the anode to produce adsorbed hydroxyl radicals according to Eq. (1) given,

(Electrode surface) $+\mathrm{H}_{2} \mathrm{O} \rightarrow$ (electrode surface $)(\mathrm{OH})$

$$
+\mathrm{H}^{+}+\mathrm{e}^{-}
$$

At the anode surface, active oxygen can be present in two states, either as physisorbed hydroxyl radicals $(\mathrm{OH})$ and/or as chemisorbed (oxygen in the porous surface of the graphite electrode). In the absence of oxidizable organics, the active oxygen produces dioxygen according to Eq. (2):

(Electrode surface) $(\cdot \mathrm{OH}) \rightarrow($ electrode surface $)+1 / 2 \mathrm{O}_{2}$

$$
+\mathrm{H}^{+}+\mathrm{e}^{-}
$$

In indirect oxidation, the addition of $\mathrm{NaCl}$ as supporting electrolyte favours the generation of $\mathrm{OCl}^{-}$radicals according to Eq. (3) as given below,

(Electrode surface $)(\mathrm{OH})+\mathrm{Cl}^{-} \rightarrow($ electrode surface $)$

$$
(\mathrm{OCl})+\mathrm{H}^{+}+2 \mathrm{e}^{-}
$$

Further, the $\mathrm{OCl}$ radicals combine with chloride ions generating the chlorine gas and thus responsible for the oxidation of organic pollutants in the bulk solution.

$$
\begin{aligned}
\text { (Electrode surface })(\cdot \mathrm{OCl})+\mathrm{Cl}^{-} \rightarrow & (\text { electrode surface }) \\
& +\mathrm{Cl}_{2}+\mathrm{e}^{-} \\
(\text {Electrode surface })(\mathrm{OCl})+\mathrm{Cl}^{-} \rightarrow & (\text { electrode surface }) \\
& +1 / 2 \mathrm{O}_{2}+\mathrm{Cl}_{2}+\mathrm{e}^{-}
\end{aligned}
$$

These sequential reactions will continue until the formation of carbon dioxide and water in the bulk solution during the electrochemical oxidation process (Bindu et al. 2000; Malpass and Motheo 2001). In direct oxidation, the rate of diffusion of organic compounds onto anode area controls the electrochemical oxidation reaction (Buso et al. 2000; Raghu and Basha 2007). On the other hand, temperature, $\mathrm{pH}$ and diffusion rate of generated oxidants determine the rate of oxidation in indirect 
electrolysis (Comninellis and Pulgarin 1999; Miwa et al. 2006; Malpass et al. 2007).

\section{Results and discussion}

\section{Effect of current density on electrochemical oxidation of catechol}

The influence of current density on the degradation of catechol containing RO concentrate was determined by varying the current density of 100,200 and $300 \mathrm{~mA} / \mathrm{cm}^{2}$. The other conditions such as initial concentration of COD $680 \mathrm{mg} / \mathrm{L}$ (for the addition of $2.25 \mathrm{mmol} / \mathrm{L}$ of catechol), native $\mathrm{pH}$ and temperature $25{ }^{\circ} \mathrm{C}$ were kept constant for the batch experimentation. At regular interval of time, the samples were collected to analyse COD values for the organic removal load. Figure 2 a shows that the increase in current density decreased the COD concentration in RO concentrate significantly. Figure $2 b$ shows the variation in instantaneous current efficiency with time at different current density in the treatment of catechol containing RO concentrate solution.

At initial stage of oxidation, graphite rod electrodes have exhibited the ICE values greater than 1.0. The high value of ICE at the beginning of electrochemical oxidation may be due to the fact that total applied current was completely utilized for the degradation of organic compound (catechol) present in RO concentrate solution. And thereafter, ICE starts to decrease beyond $30 \mathrm{~min}$ of electrochemical oxidation time $\left(t_{\mathrm{eco}}\right)$. The response suggested that beyond $30 \mathrm{~min}$, the mechanism of organic oxidation is controlled by mass transfer diffusion. A similar kind of mechanism was observed on oxidation of organics present in textile effluent (Bhaskar Raju et al. 2009). Further, the increase in applied current density $(j)$ for the organic removal decreased the current efficiency of the process. This could be due to electrode polarization effect with increase in current density and thus reduces the active surface area of the electrode significantly. The current efficiency for the current densities $(j)$ 100, 200 and $300 \mathrm{~mA} / \mathrm{cm}^{2}$ was found to be $0.67,0.37$ and $0.32 \%$, respectively. The maximum reduction in COD reduction was observed at current density of $300 \mathrm{~mA} / \mathrm{cm}^{2}$ and at electrochemical oxidation time $\left(t_{\mathrm{eco}}\right)$ of $120 \mathrm{~min}$.

\section{Effect of pH on electrochemical oxidation of catechol}

The effect of initial $\mathrm{pH}$ of catechol containing $\mathrm{RO}$ concentrate solution was varied from 2.0 to 10.0 for the electrochemical treatment, and other experimental conditions such as $j, 100 \mathrm{~mA} / \mathrm{cm}^{2}$; temperature, $25^{\circ} \mathrm{C}$; initial COD, $680 \mathrm{mg} / \mathrm{L}$; and $t_{\mathrm{eco}}, 60 \mathrm{~min}$ were fixed as constant. Figure 3 shows that the magnitude of percentage removal of COD increased significantly with the increase in solution $\mathrm{pH}$ of catechol containing $\mathrm{RO}$ concentrate solution from acidic to alkaline condition. There was an increase in removal of COD with the increase in $\mathrm{pH}$ from 2.0 to 8.0, and thereafter, for increase in $\mathrm{pH}$ up to 10.0 , the removal rate remains constant (Nematollahi et al. 2009; Hadi et al. 2013; Roya and Davood 2011). The electrochemical oxidation was found to be highly significant at neutral $\mathrm{pH}$ range. Hence, the treatment of catechol containing RO concentrate can be taken between the $\mathrm{pH}$ range of $7.0-8.0$.
Fig. 2 Electrochemical treatment of catechol containing RO concentrate solution. a Influence of applied current density $(j)$ on COD removal. b Instantaneous current efficiency (conditions: $\mathrm{pH} 7.0$; initial COD $680 \mathrm{mg} / \mathrm{L}$ and temperature $25^{\circ} \mathrm{C}$ ) (a)



(b)

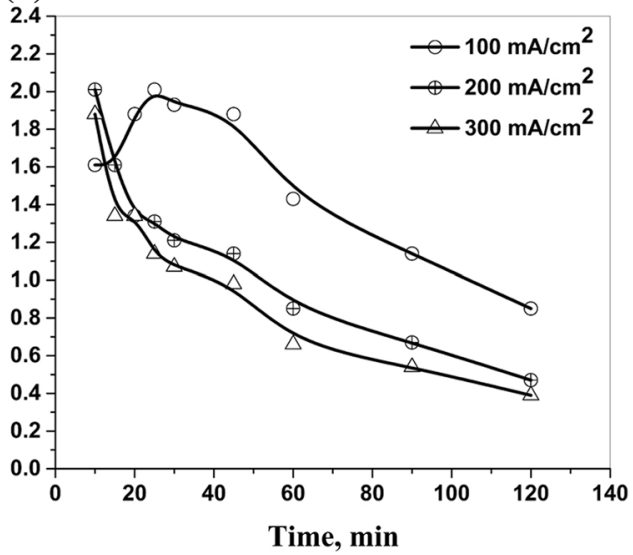




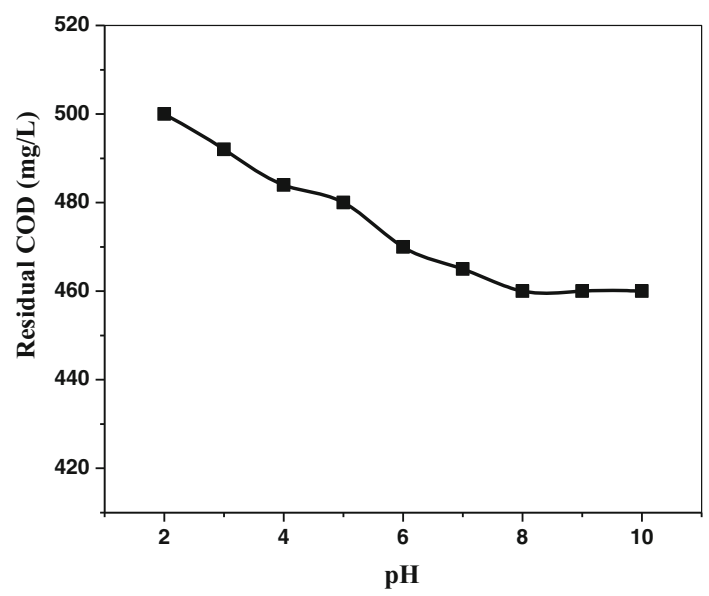

Fig. 3 Effect of initial $\mathrm{pH}$ on COD removal by electrochemical oxidation of catechol containing RO concentrate solution (conditions: $t_{\text {eco }}, 60 \mathrm{~min}$; temperature, $25^{\circ} \mathrm{C}$ and $j, 100 \mathrm{~mA} / \mathrm{cm}^{2}$ )



Fig. 4 Effect of catechol concentration on treatment of catechol containing RO concentrate solution (conditions: $t_{\mathrm{eco}}, 60 \mathrm{~min}$; temperature, $25{ }^{\circ} \mathrm{C}$ and $j, 100 \mathrm{~mA} / \mathrm{cm}^{2}$ )

\section{Effect of catechol concentration in RO concentrate solution}

The RO concentrate with different catechol concentration of $2.25,4.5$ and $9.0 \mathrm{mmol} / \mathrm{L}$ was prepared, and their respective initial COD values were found to be 680, 1000 and $1720 \mathrm{mg} / \mathrm{L}$, respectively. The batch experiments were carried out at optimum $j, 100 \mathrm{~mA} / \mathrm{cm}^{2} ; t_{\mathrm{eco}}, 60 \mathrm{~min} ; \mathrm{pH}$, 7.0; and temperature, $25^{\circ} \mathrm{C}$. Figure 4 shows the COD removal pattern of synthetic $\mathrm{RO}$ concentrate solution by electrochemical oxidation.

\section{Effect of temperature on electrochemical oxidation of catechol}

The influence of solution temperature on the removal of COD from catechol containing RO concentrate solution

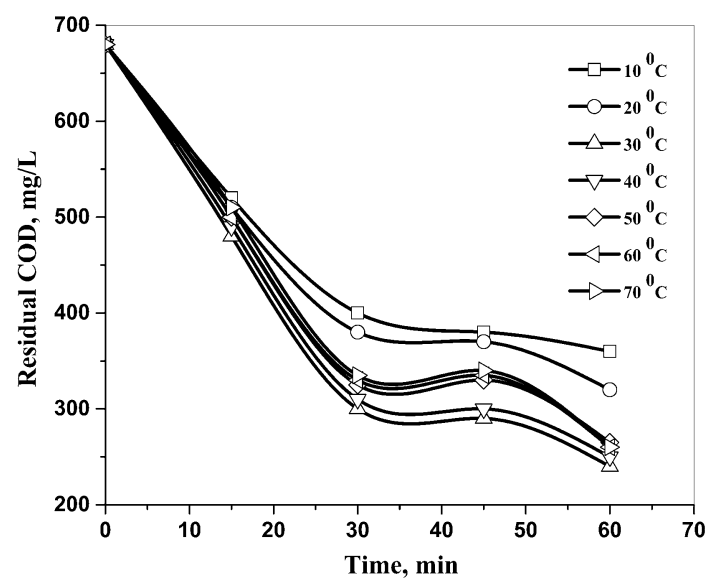

Fig. 5 Effect of solution temperature on treatment of catechol containing RO concentrate solution (conditions: $t_{\mathrm{eco}}, 60 \mathrm{~min} ; j$, $100 \mathrm{~mA} / \mathrm{cm}^{2}$ and initial COD, $680 \mathrm{mg} / \mathrm{L}$ )

was determined by varying the solution temperature from 10 to $70{ }^{\circ} \mathrm{C}$. Jacketed electrochemical cell was used to maintain the required set temperature by circulating water from thermostatically controlled water bath. All the other electrochemical parameters such as $j, 100 \mathrm{~mA} /$ $\mathrm{cm}^{2} ; t_{\text {eco }}, 60 \mathrm{~min}$; concentration of catechol, $2.25 \mathrm{mmol} /$ $\mathrm{L}$; pH, 7.0; and COD, $680 \mathrm{mg} / \mathrm{L}$ were maintained constant. Figure 5 shows that the COD removal increased with the increase in temperature up to $30^{\circ} \mathrm{C}$ and thereafter, the increase in temperature decreased the COD removal significantly. This may be due to increased molecular movement in bulk solution by the increased thermal radiation transport of organic molecules in the electrochemical cell which extends up to $30{ }^{\circ} \mathrm{C}$. Further increase in temperature might reversed the reaction by rigorous molecular collision and also favoured the generation of undesirable products which could be the reason for the increase in COD over the initial concentration with increase in temperature. Hence, the optimum temperature in further experiments was kept at $25{ }^{\circ} \mathrm{C}$.

\section{Materials of selection for the electrochemical treatment of catechol containing RO concentrate solution}

Anodes and cathodes of various materials of construction were changed to find the COD removal efficiency in electrochemical oxidation of catechol containing RO concentrate solution under batch experiment. The operating conditions were at $j, 100 \mathrm{~mA} / \mathrm{cm}^{2} ; t_{\mathrm{eco}}, 60 \mathrm{~min}$; applied potential, $4.5 \mathrm{~V}$; COD, $680 \mathrm{mg} / \mathrm{L}$; and temperature, $25^{\circ} \mathrm{C}$. Figure $6 \mathrm{a}, \mathrm{b}$ shows that high percentage removal of COD was observed with graphite/graphite electrode system than other electrode systems. 
Fig. 6 Selection of materials of construction of electrodes (anode-cathode) for electrochemical oxidation of catechol containing RO concentrate solution based on a ICE, $\mathbf{b}$ percentage of COD removal (conditions: $t_{\mathrm{eco}}$ $60 \mathrm{~min}$; temperature, $25^{\circ} \mathrm{C} ; j$, $100 \mathrm{~mA} / \mathrm{cm}^{2}$ and applied potential, $4.5 \mathrm{~V}$ )

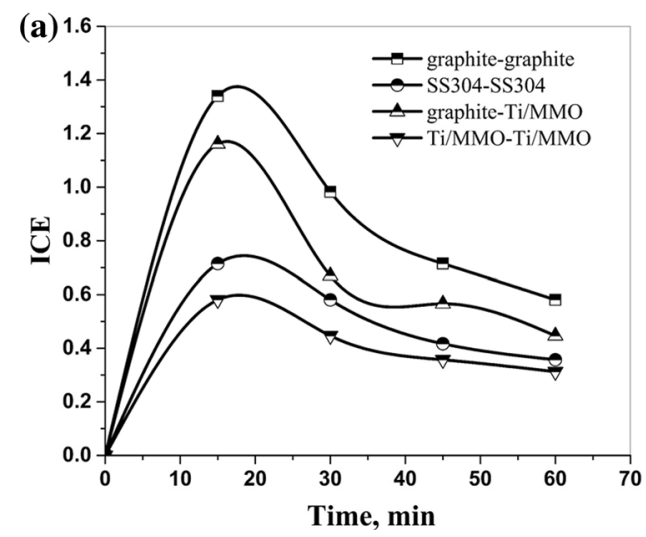

\section{Kinetic studies on electrochemical oxidation of catechol containing RO concentrate solution}

Kinetic study on the removal of catechol in terms of COD in catechol containing RO concentrate solution was analysed based on the limiting current density $\left(j_{\text {lim }}\right)$ during the electrolysis for the graphite/graphite electrode system. The $j_{\text {lim }}$ could be related to $[\mathrm{COD}]_{0}$ by the mathematical expression

$j_{\mathrm{lim}}=n F k_{\mathrm{m}}[\mathrm{COD}]_{0}$

where $j_{\mathrm{lim}}$ is the limiting current density $\left(\mathrm{mA} / \mathrm{cm}^{2}\right)$ at the instant ' $t$ ', $\mathrm{n}$ is the number of electrons transferred, $F$ is the Faraday constant $(96,487 \mathrm{C} / \mathrm{mol})$, and $k_{\mathrm{m}(\mathrm{COD})}$ is the average mass transport coefficient $(\mathrm{m} / \mathrm{s})$ based on COD removal. Then, the COD removal rate $(r)$ can be expressed as (Roberts et al. 2010),

$r=\frac{j_{\mathrm{lim}}}{n F}=k_{m}[\mathrm{COD}]$

From the mass balance of the whole system operating under batch mode, we get,

$\frac{\mathrm{d}[\mathrm{COD}]}{\mathrm{d} t}=-\frac{A}{v} r$

where $A$ is the electrode area $\left(\mathrm{m}^{2}\right)$ and $v$ is the total volume of the solution $\left(\mathrm{m}^{3}\right)$ being processed on integration and simplification, and we get,

$\ln \left(\frac{[\mathrm{COD}]_{t}}{[\mathrm{COD}]_{0}}\right)=-\frac{A k_{\mathrm{m}}}{v} t$

The plot of $\ln \left(\mathrm{COD}_{t} / \mathrm{COD}_{0}\right)$ versus time shows that the degradation of catechol in RO concentrate solution followed the pseudo-first-order rate equation as given in Eq. (9).

From the slope of the plot of $\ln \left(\mathrm{COD}_{t} / \mathrm{COD}_{0}\right)$ versus time (Fig. 7), the values of mass transfer coefficient

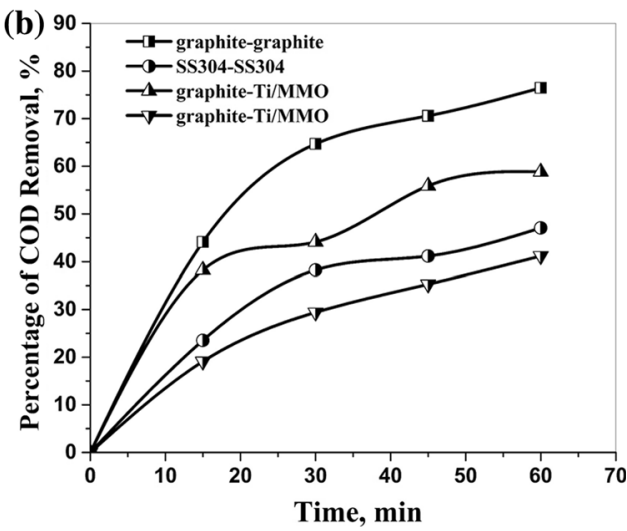

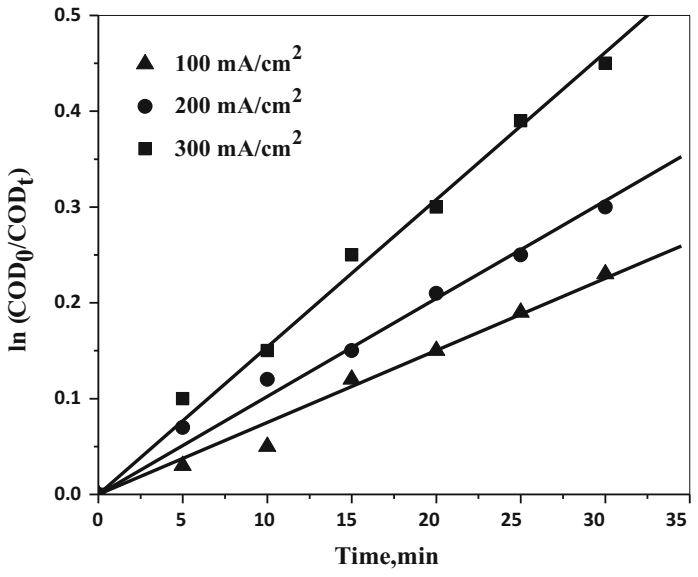

Fig. 7 Mass transfer coefficient for electrochemical oxidation of catechol containing RO concentrate solution (conditions: temperature, $25^{\circ} \mathrm{C} ; j$ and applied potential, $4.5 \mathrm{~V}$ )

Table 2 Evaluation of mass transfer coefficient, $\mathrm{k}_{\mathrm{m}}$, and limiting current density, $j_{\text {lim }}$, values at different current densities for the electrochemical oxidation of catechol containing $\mathrm{RO}$ concentrate solution (conditions: $\mathrm{COD}_{0}, 680 \mathrm{mg} / \mathrm{L}$; temperature, $25^{\circ} \mathrm{C}$ and $\mathrm{pH}$, 7.0)

\begin{tabular}{lll}
\hline $\begin{array}{l}\text { Current density, } \\
\left(\mathrm{mA} / \mathrm{cm}^{2}\right)\end{array}$ & $\begin{array}{l}\text { Mass transfer } \\
\text { coefficient, } \\
k_{\mathrm{m}}(\mathrm{m} / \mathrm{s})\end{array}$ & $\begin{array}{l}\text { Limiting current } \\
\text { density, } j_{\text {lim }} \\
\left(\mathrm{mA} / \mathrm{cm}^{2}\right)\end{array}$ \\
\hline 100 & $3.01 \times 10^{-5}$ & 246.5 \\
200 & $4.06 \times 10^{-5}$ & 333.5 \\
300 & $6.19 \times 10^{-5}$ & 507.6 \\
\hline
\end{tabular}

were calculated for the electrochemical oxidation of catechol containing RO concentrate solution. Table 2 shows that increase in current density increased the mass transfer coefficient significantly. The rate controlling mechanism for electrochemical oxidation was confirmed by evaluating the limiting current density using Eq. (7). The value of mass transfer coefficient 


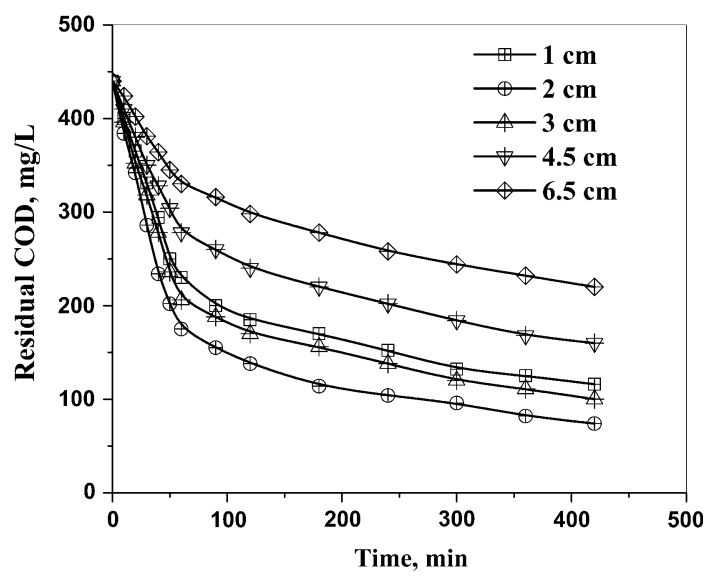

Fig. 8 Effect of inner electrode space for the treatment of catechol containing RO concentrate (conditions: current density, $300 \mathrm{~mA} / \mathrm{cm}^{2}$ and concentration, $2.25 \mathrm{mmol} / \mathrm{L}$ )

$\left(k_{\mathrm{m}}\right)$ was calculated from the slope of straight line. The value of $k_{\mathrm{m}}$ was found to be $3.00 \times 10^{-5} \mathrm{~m} / \mathrm{s}$ at optimum conditions $j, 100 \mathrm{~mA} / \mathrm{cm}^{2} ; t_{\mathrm{eco}}, 30 \mathrm{~min}$; and temperature, $25{ }^{\circ} \mathrm{C}$.

\section{Effect of electrode spacing}

The inner space between the anode and cathode electrode was varied from 1 to $6 \mathrm{~cm}$ for the evaluation of effective space for the electrochemical oxidation of catechol in RO concentrate solution. Figure 8 shows that the increase in electrode space from 1 to $2 \mathrm{~cm}$ increased the rate of COD removal $(0.77-0.87 \mathrm{mg}$ of $\mathrm{COD} / \mathrm{min})$ significantly and thereafter, increase in electrode space beyond $2-6.5 \mathrm{~cm}$ decreased the rate of COD removal from 0.87 to $0.52 \mathrm{mg}$ of $\mathrm{COD} / \mathrm{min}$. The results revealed that the effective electrode spacing between the anode and cathode is $2 \mathrm{~cm}$. Thus, the $2-\mathrm{cm}$ electrode spacing is sufficient enough to diffuse generated oxidants in bulk solution for maximum destruction of catechol. Also, the increase in space between the electrodes increased working potential for applied current density and thus increased the ohmic resistance of the electrochemical oxidation process. The working potential for electrode space 2 and $6.5 \mathrm{~cm}$ was found to be 2.2 and $5.4 \mathrm{~V}$ for the applied current density of $300 \mathrm{~mA} /$ $\mathrm{cm}^{2}$. The removal of COD during the $1 \mathrm{~cm}$ spacing was less, and this may be due to the generation of halogenated by-products. This halogenated by-products are more refractory in nature; hence, the overall removal of COD was observed to be less at $1 \mathrm{~cm}$ electrode space. The effective electrode space significantly reduces the cost of electricity by the low-voltage operation for the electrochemical oxidation than the conventionally following
Table 3 Apparent faradic efficiency and specific energy consumption for the treatment of catechol containing $\mathrm{RO}$ concentrate (conditions: catechol concentration, $2.25 \mathrm{mmol} / \mathrm{L}$ and inner electrode space, $2 \mathrm{~cm}$ )

\begin{tabular}{lll}
\hline $\begin{array}{l}\text { Current } \\
\text { density } \\
\left(\mathrm{mA} / \mathrm{cm}^{2}\right)\end{array}$ & $\begin{array}{l}\text { Apparent faradic } \\
\text { efficiency }\left(\eta_{\mathrm{F}}, \%\right)\end{array}$ & $\begin{array}{l}\text { Specific energy } \\
\text { consumption } \\
\left(E_{\mathrm{SP}}, \mathrm{kW} / \mathrm{g} \text { of COD }\right)\end{array}$ \\
\hline 100 & 57.4 & 0.11 \\
200 & 43.0 & 0.24 \\
300 & 30.8 & 0.55 \\
\hline
\end{tabular}

vertical electrode system. Also, the skill and maintenance required for the horizontally positioned electrodes are less than for the available electrochemical method.

\section{Apparent faradic efficiency and specific energy consumption}

The apparent faradic efficiency of COD removal was calculated using the following formula

$\eta_{\mathrm{F}}=\frac{(\Delta \mathrm{COD} \times V \times F)}{8 \times I \times \Delta t}$

where $\triangle \mathrm{COD}$ is the net COD removed $(\mathrm{mg} / \mathrm{L})$ after a treatment time $t, V$ is the volume of treated solution $(\mathrm{L})$, $F$ is Faradays constant (96,487 C/equiv), 8 is the equivalent weight of oxygen, $I$ is the applied current, and $\Delta t$ is the treatment duration (s). The $\eta_{\mathrm{F}}$ for COD removal was found to be (Table 3) 57.4, 43.0 and 30.8\% at 0.1, 0.2 and $0.3 \mathrm{~A}$, respectively.

Specific energy consumption $\left(E_{\mathrm{sp}}\right)$, the electric energy in kilowatt hours required to degrade a kilogram of a pollutant in water, was calculated using the formula for batch operation (Necip et al. 2015).

$E_{\mathrm{SP}}=\frac{P \times t \times 10^{6}}{V\left(C_{0}-C_{t}\right)}$

where $P$ is the rated power $(\mathrm{kW})$ of the reactor, $V$ is the volume (L) of water treated in the time $t(\mathrm{~h}), C_{0}$ and $C_{t}$ are the initial and final pollutant concentration in COD $(\mathrm{mg} / \mathrm{L})$, and the factor $10^{6}$ converts $\mathrm{mg}$ to $\mathrm{kg}$. The $\mathrm{E}_{\mathrm{SP}}$ for the removal of COD during $2 \mathrm{~h}$ at 100, 200 and $300 \mathrm{~mA} / \mathrm{cm}^{2}$ was evaluated as $0.11,0.24$ and $0.55 \mathrm{~kW} / \mathrm{g}$ of COD.

\section{Instrumental analyses}

\section{Fourier transform infrared spectroscopy (FTIR) analysis}

The catechol containing RO concentrate solution before and after electrochemical oxidation was characterized using FTIR spectroscopy. Figure 9a shows FTIR spectra of 


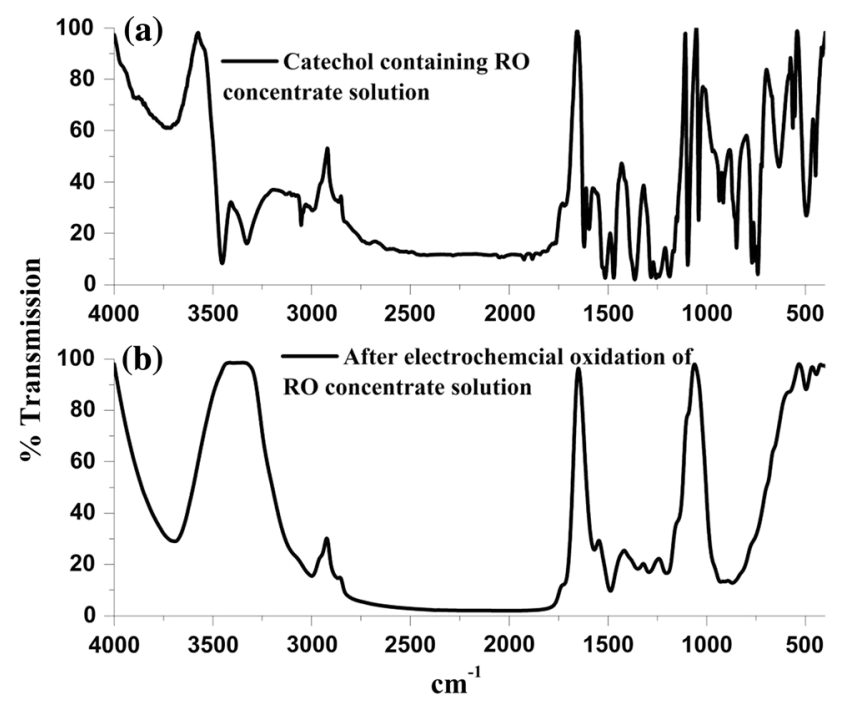

Fig. 9 FTIR spectra of a catechol containing synthetic RO concentrate solution, b solution after electrochemical oxidation of RO concentrate

catechol containing RO concentrate with broad stretching vibration peak observed at $1400-1600 \mathrm{~cm}^{-1}$, indicating the presence of aromatic $\mathrm{C}=\mathrm{C}$ functional groups, and medium stretching band at $3052 \mathrm{~cm}^{-1}$ confirms the presence of $\mathrm{C}-$ $\mathrm{H}$ functional group of catechol in initial RO concentrate solution; further, the strong stretching band at $1670-1820 \mathrm{~cm}^{-1}$ illustrates the presence of $\mathrm{C}=\mathrm{O}$ functional group.

The solutions after electrochemical oxidations of catechol containing RO concentrate (Fig. 9b) showed that there was a significant reduction in multiple peaks observed in the initial solution at $1400-1600 \mathrm{~cm}^{-1}$. This clearly confirmed the oxidation of catechol compound from RO concentrate solution.

\section{Conclusion}

Electrochemical treatment of catechol containing RO concentrate was performed using graphite electrode. The optimized conditions were found to be current density $(j)$, $100 \mathrm{~mA} / \mathrm{cm}^{2}$; electrochemical oxidation time $\left(t_{\mathrm{eco}}\right)$, $60 \mathrm{~min}$; $\mathrm{pH}, 7.0$; and temperature, $25{ }^{\circ} \mathrm{C}$ at an inner electrode space, $2 \mathrm{~cm}$. The average mass transport coefficient for the removal of catechol in terms of COD was found to be $3.0 \times 10^{-5} \mathrm{~m} / \mathrm{s}$ at optimum conditions. Fourier transform infrared spectroscopy analysis confirmed the removal of catechol by electrochemical oxidation using graphite as electrodes. The results suggested that the removal of organic pollutants in electrochemical treatment was favoured by applied current density when the applied current is less than limiting current density and mass transport was controlling step when the applied current density is higher than the limiting current density.

Acknowledgments The authors are thankful to the Council of Scientific and Industrial Research (CSIR), India, for the financial assistance to carry out this research work.

$\begin{array}{ll}\text { Abbreviations } \\ \text { RO } & \text { Reverse osmosis } \\ \text { COD } & \text { Chemical oxygen demand } \\ \text { AOP } & \text { Advanced oxidation process } \\ \text { EAOP } & \text { Electrochemical oxidation process } \\ \text { BDD } & \text { Boron-doped diamond } \\ \text { ETP } & \text { Effluent treatment plant } \\ i_{\mathrm{L}} & \text { Limiting current density }\left(\mathrm{mA} / \mathrm{cm}^{2}\right) \\ F & \text { Faraday constant, } 96,487 \mathrm{C} / \mathrm{mol}^{2} \\ k_{\mathrm{m}} & \text { Average mass transport coefficient }(\mathrm{m} / \mathrm{s}) \\ A & \left.\text { Electrode area (cm }{ }^{2}\right) \\ V & \text { Volume of the solution }(\mathrm{L}) \\ k_{\mathrm{app}} & \text { Apparent oxidation rate constant }\left(\mathrm{mg} / \mathrm{m}^{2} \mathrm{~s}\right) \\ \eta_{\mathrm{F}} & \text { Apparent current efficiency } \\ E_{\mathrm{sp}} & \text { Energy consumption }(\mathrm{kW} / \mathrm{g} \text { of COD) }\end{array}$

\section{References}

American Public Health Association (1999) Standards methods for the examination of water and waste water, 20th edn. American Public Health Association, Washington

Bhaskar Raju G, Thalamadai Karuppiah M, Latha SS, Latha Priya D, Parvathy S, Prabhakar S (2009) Electrochemical pretreatment of textile effluents and effect of electrode materials on the removal of organics. Desalination 249:167-174

Bindu K, Velusamy S, Basha CA, Vijayavalli R (2000) Mediated electrochemical oxidation of organic pollutants in wastewater treatment. Indian J Environ Health 4:185-191

Boopathy R, Sekaran G (2014) Electrochemical treatment of reverse osmosis concentrate generated by the leather industry using a $\mathrm{Cu}$-graphite electrode. RSC Adv 4:9971-9979

Boopathy R, Gnanamani A, Mandal AB, Sekaran G (2012) A first report on the selective precipitation of sodium chloride from the evaporated residue of reverse osmosis reject salt generated from the leather industry. Ind Eng Chem Res 51:5527-5534

Buso A, Balbo L, Giomo M, Farnia G, Sandona G (2000) Electrochemical removal of tannins from aqueous solutions. Ind Eng Chem Res 39:494-499

Chaplin B, Schrader G, Farrel J (2010) Electrochemical destruction of nitrosodimethylamine in reverse osmosis concentrates using 
boron-doped diamond film electrodes. Environ Sci Technol 44:4264-4269

Chelme-Ayala P, Smith DW, El-Din MG (2009) Membrane concentrate management options: a comprehensive critical review. Can J Civil Eng 36:1107-1119

Choo WL, Jeffrey MI, Robertson SG (2006) Anlaysis of leaching and cementation reaction kinetics: correcting for volume changes in a laboratory studies. Hydrometallurgy 82:110-116

Comninellis C, Pulgarin C (1999) Electrochemical oxidation of phenol for wastewater treatment using $\mathrm{SnO}_{2}$ anodes. J Appl Electrochem 23:108-112

Dialynas E, Mantzavinos D, Diamadopoulos E (2008) Advanced treatment of the reverse osmosis concentrates produced during reclamation of municipal wastewater. Water Res 42:4603-4608

Einav R, Lokiec F (2003) Environmental aspects of a desalination plant in Ashkelon. Desalination 156:79-85

Hadi B, Davood N, Fahimeh V (2013) Electrochemical oxidation of some aminophenols in various pHs. J Electrochem Soc 160:H41-H46

Hege KV, Verhaege M, Verstraete W (2004) Electro-oxidative abatement of low salinity reverse osmosis membrane concentrates. Water Res 38:1550-1558

Kaya A, Onac C, Korkmaz Alpoguz H, Yilmaz A, Atar N (2016) Removal of $\mathrm{Cr}(\mathrm{VI})$ through calixarene based polymer inclusion membrane from chrome plating bath water. Chem Eng J 283:141-149

Malpass GRP, Motheo AJ (2001) Electro-oxidation of formaldehyde methanol solutions on $\mathrm{Ti} / \mathrm{Ru} 0.3 \mathrm{Ti} 0.7 \mathrm{O}_{2}$ electrodes using a filterpress cell. J Appl Electrochem 31:1351-1357

Malpass GRP, Miwa DW, Mortari DA, Machado SAS, Motheo AJ (2007) Decolorisation of real textile waste using electrochemical techniques: effect of the chloride concentration. Water Res 41:2969-2977

Mauguin G, Corsin P (2005) Concentrate and other waste disposals from SWRO plants: characterization and reduction of their environmental impact. Desalination 182:355-364

Mehmet LY, Tanju E, Necip A (2014a) A novel efficient photocatalyst based on $\mathrm{TiO}_{2}$ nanoparticles involved boron enrichment waste for photocatalytic degradation of atrazine. Chem Eng J 250:288-294
Mehmet LY, Tanju E, Necip A (2014b) A novel and sensitive electrochemical DNA biosensor based on Fe@Au nanoparticles decorated graphene oxide. Electrochim Acta 125:38-47

Meneses M, Pasqualino JC, Ceespedes-Saanchez R, Castells F (2010) Alternatives for reducing the environmental impact of the main residue from a desalination plant. J Ind Ecol 14:512-527

Miwa DW, Malpass GRP, Machado SAS, Motheo AJ (2006) Electrochemical degradation of carbaryl on oxide electrodes. Water Res 40:3281-3289

Muhammad S, Shahid A, Muhammad AS, Atta-ul-Haq MM, Muhammad Y (2015) $\mathrm{Pt} / \mathrm{Al}_{2} \mathrm{O}_{3}$ catalyzed decolorization of rhodamine B dye in aqueous medium. Chaing Mai J Sci 42:730-744

Muneer M, Adeel S, Bhatti IA, Jamal MA, Rehman FU (2015) Removal of reactive orange $\mathrm{P} 3 \mathrm{r}$ dye by oxidative pathway. Oxid Commun 38:808-817

Murugananthan V, Bhaskar Raju G G, Prabhakar S (2005) Removal of tannins and polyhydroxy phenols by electro-chemical techniques. J Chem Technol Biotechnol 80:1188-1197

Necip A, Tanju E, Mehmet LY, Ma HK, Bermali D (2015) Magnetic iron oxide and iron oxide@gold nanoparticle anchored nitrogen and sulfur-functionalized reduced graphene oxide electrocatalyst for methanol oxidation. RSC Adv 5:26402-26409

Nematollahi D, Shayani-Jam H, Alimoradi M, Niroomand S (2009) Electrochemical oxidation of acetaminophen in aqueous solutions: kinetic evaluation of hydrolysis, hydroxylation and dimerization processes. Electrochim Acta 54:7407-7415

Perez G, Fernandez-Alba AR, Urtiaga AM, Ortiz I (2010) Electrooxidation of reverse osmosis concentrates generated in tertiary water treatment. Water Res 44:2763-2772

Pophali GR, Hedau S, Gedam N, Rao NN, Nandy T (2011) Treatment of refractory organics from membrane rejects using ozonation. J Hazard Mater 189:273-277

Raghu S, Basha CA (2007) Electrochemical treatment of procion block 5B using cylindrical flow reactor-a pilot plant study. J Hazard Mater 139:381-390

Roberts DA, Johnston EL, Knott NA (2010) Impacts of desalination plant discharges on the marine environment: a critical review of published studies. Water Res 44:5117-5128

Roya E, Davood N (2011) Electrochemical oxidation of 4-morpholinoaniline in aqueous solutions: Synthesis of a new trimer of 4-morpholinoaniline. Electrochim Acta 56:3899-3904 
Vyrides I, Stuckey DC (2009) A modified method for the determination of chemical oxygen demand (COD) for samples with high salinity and low organics. Biores Technol 100:979-982

Westerhoff P, Moon H, Minakata D, Crittenden J (2009) Oxidation of organics in retentates from reverse osmosis wastewater reuse facilities. Water Res 43:3992-3998

Zhou T, Lim TT, Chin SS, Fane AG (2011a) Treatment of organics in reverse osmosis concentrate from a municipal wastewater reclamation plant: feasibility test of advanced oxidation processes with/without pre-treatment. Chem Eng J 166:932-939

Zhou MH, Liu L, Jiao YL, Wang Q, Tan QQ (2011b) Treatment of high-salinity reverse osmosis concentrate by electrochemical oxidation on BDD and DSA electrodes. Desalination 277:201-206 